\title{
GIS Developments for Ecosystem-based Marine Spatial Planning and the Challenges Faced in Indonesia
}

\author{
Karlina Triana ${ }^{1, *}$ and A'an Johan Wahyudi ${ }^{1}$ \\ ${ }^{1}$ Research Center for Oceanography, Indonesian Institute of Sciences, Jl. Jend. Gatot Subroto 10, Jakarta 12710, Indonesia \\ ${ }^{*}$ Corresponding author: karlina.triana@gmail.com
}

\author{
KEYWORDS \\ Ecosystem-based \\ GIS \\ Indonesia \\ Marine Spatial Planning \\ Remote sensing
}

\begin{abstract}
Aiming to lessen degradations and effects on marine ecosystems, Marine Spatial Planning is used as a management method with a purpose to help lead the development and used in the marine environment. The stages of the planning are collection, management, and analysis of spatial data, and also decision support systems. This method requires tools to be able to achieve the goals effectively. Geographic Information System (GIS) and remote sensing can efficiently and effectively be used to access and summarize spatial data into information forms to evaluate the Marine Spatial Planning projects. GIS and remote sensing obviously have an essential function in terms of its opportunities and its capabilities for development and projections in the future. This review is intended to produce critical description on the study of GIS development for Marine Spatial Planning. Furthermore, this review is intended to foresee the challenges faced in its implementation in Indonesia.
\end{abstract}

(c) The Author(s) 2019. This article is distributed under a Creative Commons Attribution-ShareAlike 4.0 International license.

\section{INTRODUCTION}

Marine resources protection from overexploitation and derivation is substantially important to make sure of their sustainability. Marine Spatial Planning is used as a management method with a purpose to help lead the development and used in the marine environment (Paxinos et al. 2008). Marine Spatial Planning has the capability to be an essential approach to lower or evade issues arise from singlespecies management, regional decision making, and gaps between jurisdictional and ecological boundaries (Crowder and Norse 2008). A study area of Marine Spatial Planning hosts an enormous variety of human activities that illustrate unique ranges of coexistence or spatial overlap between these uses. The latter might also suggest the existence of interactions and possible conflicts among overlapping human activities (Kokkali et al. 2014).

Presenting a combination of land uses, from conservation to extractive use, with the natural capabilities of an area will help ensure that people have the desire to preserve biodiversity (Vold and Buffett 2008). At the same time, the supply of goods and services can be carried out simultaneously and continuously. This combination can be achieved by the Marine Spatial Planning method.

Ehler and Douvere (2009) detailed the step-by-step approach method for Marine Spatial Planning implementation. Firstly, 'the needs' must be identified so that the authority can be established and the financial support can be assessed. Secondly, organize the pre-planning process and participation of the stakeholder. Thirdly, define and analyze the existing and future conditions. Spatial management plan should be prepared and implemented after the plan was approved by the governance system. In this im- plementation stage, the performance should be monitored and evaluated before adapted in regional scale.

To realize the complicated Marine Spatial Planning projects, planners require a tool to collect, manage, process and analyze the marine ecosystem data. Geographic Information System (GIS) and remote sensing can efficiently and effectively be used to access and summarize spatial data into information forms to evaluate the marine ecosystem data. The following will review some of the findings from GIS and remote sensing technology using that has been studied and analyzed by experts related to the application of Marine Spatial Planning methods, and also the challenges faced in its implementation in Indonesia.

\section{MARINE SPATIAL PLANNING IN INDONESIA}

Indonesia is the largest maritime country with wide-scale seascapes and thousands of large and small islands. The geographical position of the Indonesian seas lies between the crossing of two continents and two oceans as well as one of the arteries of international trade. The seas in Indonesia have a lot of uncountable potential marine and fisheries resources. Based on the Indonesian Ministry of Maritime and Fisheries (in Dermawan (2017)), Indonesia is known as the largest Marine Mega-Biodiversity nation in the world, with 8,500 fish species (encompassing $37 \%$ of the world's fish species), 555 seaweed species, and 950 coral biota species. The potential of Indonesia's marine fisheries resource capturing is around 6.5 million tons/year, while the potential for brackish aquaculture is 2.96 million hectares and marine cultivation reaches an area of 12.55 million hectares.

The Indonesian Ministry of Maritime Affairs and Fisheries has a mission to place the Marine Spatial Planning in 
Indonesia into a powerful management system that prioritizes people's welfare. This is supported by the making of three pillars, that is planning, management and utilization, and controlling. The goal to be achieved in the planning stage is to realize the planning of coastal and integrated islands. The ideal to be achieved at the management stage is to utilize, protect and preserve coastal, marine, and small island resources, while the objective at the utilization stage is to improve the governance and control of coastal, marine, and small island spaces. The last is the controlling stage that has a goal to control the using of marine space and resources for the welfare of the community (Dermawan 2017).

The development of the maritime sector in Indonesia is still not properly optimal, such as the utilization of fishery products that have not been well explored, the utilization of marine and aquatic activities for safe power generation, optimization of mineral and petroleum content that spreads in various water locations, the fast and safe sea transportation development, and the utilization of other maritime potentials scattered on the coast, islands and small islands with different characteristics (Shalihati 2014). Those are the results of the not maximal implementations of Marine Spatial Planning because of the lack of information about the marine resource potential along with the management of the data owned by each island/region management in Indonesia. With the presence of GIS and remote sensing expected to be able to help recognize the potential that exists, the model resulting from this method will also be beneficial for optimal utilization of coastal and marine resources.

\section{USE OF GEOGRAPHIC INFORMATION SYSTEM (GIS)}

Geographical Information System (GIS) is a system used to manipulate and analyze information that is distributed spatially using a computer. In the development of Marine Spatial Planning, GIS software is used to store, analyze, and display data that has been collected. Considerations behind planning models are developed based on management activities in ecosystem capacity (Paxinos et al. 2008). The geospatial information displayed is certainly not only information on location coordinates but also includes other information such as land use, tidal conditions, potential fisheries, mining potential, population potential, culture, and other information (Sarno 2013). The preparation of Marine Spatial Planning using GIS as a tool can be developed for other islands in all Indonesian territorial waters, then mapping the island and identifying the potential resources will be easier to invent and inventory to the further planning and development steps.

\subsection{Spatial Data Collection and Management}

Spatial data for Marine Spatial Planning can be collected from the environmental, social-economic, and marine ecosystem's cultural values. They can be obtained from a variety of sources, including kinds of literature, published papers and research, information from community and corporations, private companies and government agencies such as fishery, heritage, transportation, forestry, and environmental departments (Paxinos et al. 2008). The data collecting considers both ecosystem components (habitat types and species) and human activities and tends to identify their spatial patterns within the case observe location (Kokkali et al. 2014). The main steps within the Marine Spatial planning scheme related to the management and the use of data and information (Ehler and Douvere 2009) are shown in Figure 1.
Mapping biophysical and human use in oceans conditions also important to recognize the unique marine organisms' aggregates or associations. Simultaneously, researchers need to delineate the area used by humans and also juridical and political adjustments that concerned in those areas. Socio-economic layers might also spot the spatial distribution of recreational or tourism activities such as scuba diving, sailing, fishing, aquaculture, and also other activities like oil and gas exploration and/or development, shipping, and so on (Crowder and Norse 2008).

The inventory of marine resources is very necessary considering the complexity of the ecosystems in each island. For example, coral reef ecosystems, seagrass beds, beaches, bays, straits, estuaries, deltas, mangroves, tidal and oceanic regions. The inventory is done by mapping the islands and the ecosystem components, then identifying existing resources with field surveys and remote sensing technology. For this reason, the first thing that needs to be done is spatial island inventory and a description of the island's potential (Shalihati 2014). An inventory carried out by a number of islands owned by the Indonesian state.

Data were arranged into feature groups/datasets with similar 'issues' consist of physical environmental characteristics, marine resources ecological distributions, legal boundaries and human use. Each of which contains a number of correlated characteristic classes or 'layers' classified by name, source, geometry, and geoprocessing carried out. All data were imported and standardized using Spatial Analyst and 3D Analyst extensions of ArcGIS applications (Baldwin and Mahon 2014).

\subsection{Spatial Data Processing and Analyzing}

The analysis activities that collect and sum up the environmental, biological, and ecological information available in the study area is called spatial ecological modeling (Stamoulis and Delevaux 2015). Therefore, this work generates spatial information from the extent and scale that is important for Marine Spatial Planning and the resulting map products extend to expensive and spatially constrained field-based measurements. Many GIS data collected into thematic layers, images, charts, and sea maps are imported into ArcGIS and require additional processing and preparation. The existing supporting data such as bathymetry or geomorphology data is also collected and processed to in-

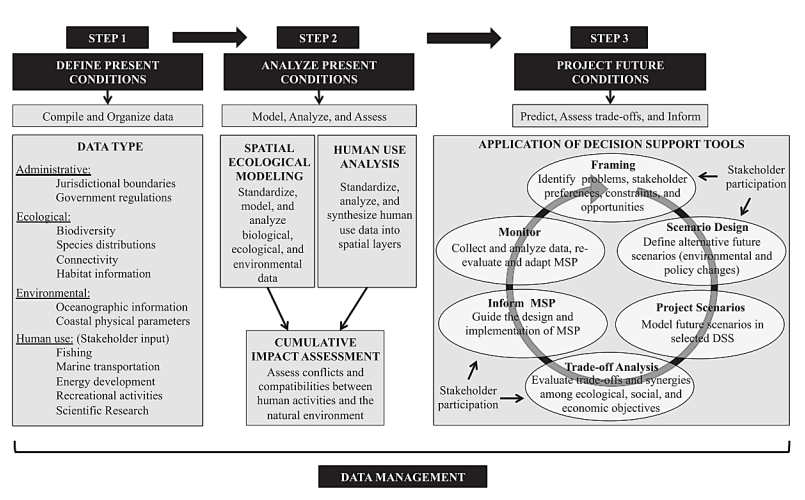

FIGURE 1. Main steps in the Marine Spatial Planning procedure related to the management and the use of data and information (Ehler and Douvere 2009). Step 1: Define the current state through collecting data; Step 2: Analyze the current state using the method of spatial ecological modeling, the analysis of human use, and the assessment of cumulative impact; and Step 3: Project the future state using decision support systems and framework modeling. 
crease the accuracy of the seafloor topography and then produce bathymetry isolation (Baldwin and Mahon 2014).

Another important part of Marine Spatial Planning is analyzing existing conditions to foresee the future (Ehler and Douvere 2009). Under the realm of GIS, many tools and applications have been developed for this goal. The mapping of important ecological and biological areas and also human use were included in the analysis. Further analysis of the ecological-based evaluation of cumulative impacts is to evaluate the possibility of conflict between human needs and environmental sustainability (Stamoulis and Delevaux 2015). Ehler and Douvere (2009) recommend a conflict identify method within existing human needs and activities. As part of the Marine Spatial Planning, standardization needs to be done on human use data obtained into the spatial layer and then stacked up in GIS to recognize existing conflicts or possible conflicts between human needs and activities. This method includes integrated methods that are applied at various scales and need to be represented and integrated accurately with temporal and spatial components (Stamoulis and Delevaux 2015).

In a study by Syofyan et al. (2010), the suitability of cage net and seaweed areas in Bunguran Island, Natuna, GIS and remote sensing was used as tools to measure, manage, analyze, and display data. The data collection technique used in this study was the field survey. The process of determining the suitability of the area is carried out by using spatial operations by utilizing GIS applications. The spatial operation used is an overlay operation that stacking overlays of spatial data union. One of the effective functions in GIS used is the spatial analysis method. The analysis method used is the weighted overlay, which is a technique for applying a rating scale to distinguish input into an integrated analysis. Weighted overlays give consideration to the parameters or criteria specified in a suitability selection process. The result of this research is the zoning areas group that answered the objectives to find a suitable area. Study about marine area suitability with GIS assistance as a tool can developed into a Marine Spatial Planning.

Halpern et al. (2008) produce the map of human impacts on marine ecosystems on a global scale. Although the scale may be too broad for most marine planning efforts, the maps generated can help inform the role and the purpose of Marine Spatial Planning. However, analytical methods can be adapted to describe the impact of humans on a better standard by sharping the data and technique used to measure, integrate, and assess the effects of various stressors working on various scales. The practical GIS applications are also used to define and analyze the marine evaluation of Grenada, Caribbean Islands (Baldwin and Mahon 2014). The study consists of marine resources and related human activities mapping, coastal and marine resources value estimating, priority conservation regions assessments, fishing activities spatial visualization, management spatial evaluation, and buying and selling business.

\subsection{Remote Sensing Applications}

Marine Spatial Planning is ideas that integrate integrated sciences and aspects in the environmental and socioeconomic scope, which might successively be learned using remote sensing technologies and other supporting techniques to resulting beneficial information from collected data (Figure 2). The main idea presented is to connect the concept of earth observation remote sensing with spatial Marine Spatial Planning. Remote sensing provides well-timed data in high temporal resolution on the inter- est area as they deliver persistent proof and help out the decision-makers (Ouellette and Getinet 2016).

The new tools, such as quantitative analysis, geospatial analysis, molecular analysis, telemetry, and modeling, have been vigorously developed on remote sensing. These tools were used to learn more about the marine ecosystems spatial-temporal dynamics and environmental variation of the organism's component (Crowder and Norse 2008). With the developed tools and equipment, the user was expected to widen their knowledge about the cycle of population dynamics in marine habitats.

The technique of remote sensing with the supplementary data can delineate ecosystems based on their similar characteristics. And also, the borderline was created according to the ecosystem-based method that represents the function of marine area allocation, such as Marine Protected Area allocation and/or no-exploitation area allocation (Kachelriess et al. 2014). Remote sensing is surely beneficial in quantifying variables and acquire biodiversity parameters for the Essential Biodiversity Variables (EBVs) in the stage of being approved as a standard assessment of biodiversity (Pereira et al. 2013) to defines a well-suit coastal region for Marine Protected Area implementation (Maina et al. 2015).

In Indonesia, remote sensing satellites have also been used to determine the characteristics of the seas. Climatological data used as parameters include sea surface temperature, wind direction and speed, chlorophyll, and the anomaly of sea surface height (Swardika et al. 2012). Sea surface temperature data is derived from the TRMM satellite while wind speed data is derived from the DMSP satellite. From the Quick Scatterometer satellite, wind speed and wind direction data can be obtained. And finally, Chlorophyll data is derived from the SeaStar satellite and SSHA data is obtained from the TOPEX/Poseidon and Jason satellites.

For fishery industries, remote sensing is a powerful tool that can bolster the fishery product potentials (Zainuddin et al. 2006) and also helping to regulate fishery industries at a preservation level by monitoring protected areas and fish stock depleting. Initially, remote sensing was used to re-

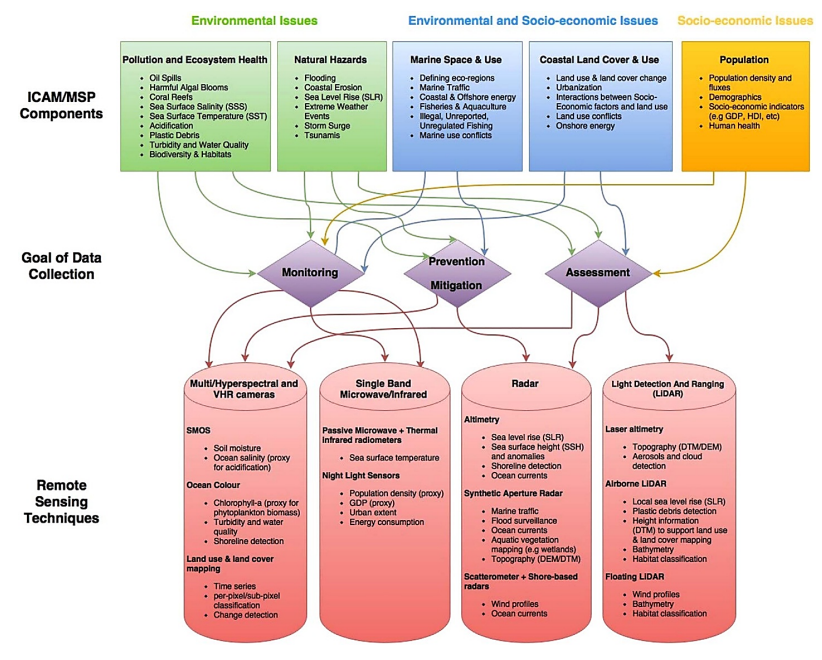

FIGURE 2. The conceptual framework: the Integrated Coastal and Marine Areas Management (ICAM) and Marine Spatial Planning (MSP) components need remote sensing supervision requisitions, delivered by the data collection targets, and each data collection target can be accomplished by various remote sensing applications (Ouellette and Getinet 2016). 
duce fish search time and find suitable parameters for fish assemblage such as sea surface temperature, phytoplankton existence, etc., but now also supported by the latest tools such as IR/MW radiometers to see sea colors and airbone SAR and LiDAR applications to distinguish small surface waves produced by a group of sea animals (Santos 2000), etc. This method may lower the costs of fish exploration too.

Aquaculture is also a very potential sector of remote sensing application because its activity is straight dependent on the condition of water and the presence of nutrient that obtained from the sea color (Longdill 2008) and water roughness. Based on APEM (2016), water quality studies located in basins or watersheds also able to help supervise hydropower plants and avoid dam blockage.

There is no doubt that the challenges faced in our sustainable marine management require integrated solutions from many research sectors. Oceanographers involved in Marine Spatial Planning should not miss the opportunity to benefit from new findings in ocean remote sensing studies and collaborate them into the decision-makers (government and/or stakeholder) long-term maritime planning and management.

\section{DECISION SUPPORT SYSTEMS}

The model or zoning area boundaries produced by GIS can help authorities make the right decisions in Marine Spatial Planning. A spatial overlapping synthesis between human use and ecosystem components is an important input for Marine Spatial Planning effectiveness. This is because the overall goal is to achieve social and economic goals while also protect marine ecosystems. It is clear that sustainable development of human activities is interdependent on the sustainability of existing activities that are distributed in the same place and simultaneously to protect the clause of ecosystem goods and services (Kokkali et al. 2014).

Planning management on an appropriate scale is necessary for creating comprehensive spatial planning to facilitate ecosystem-based management. "If it's too large, you will lose important details. But if it's too small, you will be difficult in making decisions" (Norse 2010). Marine Planning does not aim to solve all problems of using, competition, and conflict in the planning area. There may be several resolutions for each activity that will arise as a result of Marine Spatial Planning (Paxinos et al. 2008).

To accommodate and harmonize the diverse interests of the community, a comprehensive ecosystem-based Marine Spatial Planning may lessen regulation doubtfulness, non-essential costs and loss of biodiversity as a result of sectoral management. Comprehensive in this case means two things, namely: (1) all areas within the jurisdiction are managed spatially and (2) all legitimate activities in the area are included. According to Norse (2010), if an activity does not have public support, there is no need to make space for it, but a smart spatial planning system must provide fair opportunities for legitimate interests. The aim is to make their special needs known and heard whether they focus on conservation or special use that is obsolete or the latest.

To achieve the goals in ecosystem-based marine management, the key is designing an organized system that harmonizes stakeholder incentives with management objectives. The Marine Spatial Planning that entirely integrates ecosystem frameworks and collaborates socio-economic and administration layers could establish the basis for sufficient marine ecosystem preservation and prudent marine resource exploitation (Crowder and Norse 2008).

\section{THE CHALLENGES IN INDONESIA}

Referred from Nainggolan (2016), in the Indonesian maritime affairs, there are at least 11 institutions, each of which has its main duties and functions as well as program activities and/or plans related to the regulations of marine resources. The agency includes: 1) Ministry of Maritime Affairs and Fisheries (KKP); 2) National Land Agency (BPN); 3) Ministry of Environment (KLHK); 4) Ministry of Energy and Mineral Resources (ESDM); 5) Ministry of Finance; 6) Directorate General of Customs and Excise; 7) Directorate General of Immigration; 8). Department of Transportation; 9) Department General of Plantation; 10) Indonesian National Navy Armed Forces; and 11) Aquatic Police. There are several overlapping authorities among these agencies (Larasati 2017). For example, the division for controlling marine and fisheries resources is dispersed in several agencies under different department but in the same work domain and the same marine environment location. The next problem is related to the ego and the competition of each agency interest. This thing cannot be separated from the desire to maintain and strengthen the existence of each agency so that there is a tendency for the apparatus of each agency to prioritize the interests of the department.

Another challenge is that the lack of researchers with the ability to using GIS can take longer time in running Marine Spatial Planning. By mastering basic GIS application can help researchers to save time in doing their work. They should be able to do simple GIS applications such as plotting variables and creating parameter classes so that basic GIS training needs to be taught to each marine researcher. Also, to reduce the amount of non-standard variation from the planning maps produced by researchers and government agencies, we need to pay attention to the symbology system of the map. In the layout process of a map, choosing the symbology is a very important step because with symbology we can distinguish information in spatial data. In an effort to realize the implementation of standardized geospatial information, BIG collaborates with the National Standardization Agency (BSN) to make the Indonesian National Standard (SNI) for the technical specifications of the Earth maps presentation.

GIS technology has now been applied in the Indonesian maritime sector. The Ministry of Maritime Affairs and Fisheries of Indonesia (KKP) is developing a Zoning Plan for Coastal Areas and Small Islands (in Indonesian government scope called RZWP3K) for 34 provinces in Indonesia (Ministry of Maritime Affairs and Fisheries Indonesia 2013). The RZWP3K drafting process and data such as space allocation, coastal ecosystems, oceanography, geology and geomorphology, utilization of existing marine space, socioeconomic and cultural areas, provincial sea management areas, the interactive map application, and RZWP3K map results are published in an accessible geoportal websitebased. This database publication page can be accessed at https://seanode.id.

The Ministry of Agrarian Affairs and Spatial Planning of Indonesia (ATR) in collaboration with the Geospatial Information Agency (BIG) is also developing a geoportal called GISTARU which contains the publication of Indonesian spatial plan maps along with the sea area (Pribadi 2018). BIG itself has launched thematic maps called 'One Map IG' to support coastal, marine and fisheries development, including Mangrove One Map, Seagrass One Map and National Marine Characteristic One Map. In addition to the One Map, BIG has carried out many mapping activities including Salt Land Mapping, Coastal Mangrove Ecosystem Mapping 
(Density, Species, Carbon), Coastal Coral Reef Mapping, Seagrass Coastal Habitat and Ecoregion Mapping, Marine Characteristics Mapping, Direction, and Flow Speed Mapping. All of these innovations are presented in geospatial data and information to support the national ecosystembased Marine Spatial Planning.

With the support and availability of research equipment and also the data provided by national agency or government (as mentioned in the paragraph above), Indonesian researchers should maximize the research field towards future ecosystem condition analysis or moredetailed ecosystem components (habitat types and species) analysis through modelling and prediction. Many precursors of advanced global research studies can be learned with GIS and remote sensing as tools. Fish species that have never been recorded before found in American Samoa (Brown and Allen 2008), the characteristic of these fish is small, cryptic, and nocturnal. The forecast for habitat quality under climate change scenarios also can be done with the help of remote sensing (Requena-Mullor et al. 2017). Arenas-Castro et al. (2019) also studied the rare species abundance patterns prediction with satellitederived ecosystem functioning attributes. These studies are only a few examples of global researches that will motivate and encourage national researchers to dig deeper into GIS and remote sensing applications for Indonesian marine ecosystems.

Another thing that also important in the implementation of Marine Spatial Planning is community participation in complying the established Marine Spatial Planning. The risks of conflict between the Marine Spatial Planning and the community who lives in the maritime sector may still occur. It is possible for a fisherman to live well before the Marine Spatial Planning in his livelihood area is established, but then after the Marine Spatial Planning is applied for the sustainability and the health of the marine ecosystem and resources it limits the fishermen in strengthening his economic side. The Indonesian government certainly does not want communities who make a living through marine resources to feel harmed and disadvantages by Marine Spatial Planning implementations. So that the government, researchers, and communities must collaborate together in developing Marine Spatial Planning for the people welfare and the sustainability of marine resources in Indonesia.

\section{CONCLUSION}

With a purpose to guide development and utilization within the marine environment, Marine Spatial Planning components are the collection, the management, and the analysis of spatial data, and also decision support systems. Marine Spatial Planning will produce models that will assist deliver information about functional and sustainable use to all marine environment users. The concept is to unite and display marine environment data in a simple way. Successful Marine Spatial Planning starts by incorporating all involved at the local level, then seeking government assistance to implement stakeholder defined programs. Marine Spatial Planning strategy can maximize benefits to the people, accommodate many specific regional objectives, and have an economic focus with concern on sustainable development and marine environment preservation along with minimizing disputes among resource users.

GIS technology has now been applied in the Indonesian maritime sector. All of the innovations are presented in geospatial data and information to support the national Marine Spatial Planning. Studies about structure, func- tions, and marine ecosystems interaction must be developed and deepened in order to apply more related GIS and especially remote sensing applications. Research results that have been developed previously must be compiled in a global database, examined and measured empirically to validating of the approach effectiveness. The abundance of coastal and marine research using GIS and remote sensing shows that Indonesia has reliable experts in the marine field, therefore a realization and Indonesian citizen participation is needed for the implementation.

\section{REFERENCES}

APEM. 2016. Marine Field Surveys. [accessed 2019 Sep 5]. http://www.apemltd.co.uk/service/marine-field-s urveys.

Arenas-Castro S, Regos A, Gonçalves JF, Alcaraz-Segura D, Honrado J. 2019. Remotely sensed variables of ecosystem functioning support robust predictions of abundance patterns for rare species. Remote Sens. 11(18):2086. doi:10.3390/rs11182086.

Baldwin K, Mahon R. 2014. A participatory GIS for marine spatial planning in the Grenadine Islands. Electron J Inf Syst Dev Countries. 63(1):1-18. doi:10.1002/j.1681-4835. 2014.tb00452.x.

Brown DP, Allen GR. 2008. GIS derived spatial analysis as a tool to predict nearshore coral reef fish species presence in American Samoa. Proceedings of the 11th International Coral Reef Symposium; Ft. Lauderdale, United States. p. 598-601.

Crowder L, Norse E. 2008. Essential ecological insights for marine ecosystem-based management and marine spatial planning. Mar Policy. 32(5):772-778. doi:10.1016/j. marpol.2008.03.012.

Dermawan A. 2017. Pengelolaan ruang laut [Marine spatial management]. Technical report. Jakarta: Ministry of Maritime Affairs and Fisheries Indonesia.

Ehler C, Douvere F. 2009. Marine spatial planning: a stepby-step approach toward ecosystem-based management. Paris: Intergovernmental Oceanographic Commission. https://www.oceanbestpractices.net/handl e/11329/459.

Halpern BS, Walbridge S, Selkoe KA, Kappel CV, Micheli F, D’Agrosa C, Bruno JF, Casey KS, Ebert C, Fox HE, Fujita R, Heinemann D, Lenihan HS, Madin EM, Perry MT, Selig ER, Spalding M, Steneck R, Watson R. 2008. A global map of human impact on marine ecosystems. Science. 319(5865):948-952. doi:10.1126/science.1149345.

Kachelriess D, Wegmann M, Gollock M, Pettorelli N. 2014. The application of remote sensing for marine protected area management. Ecol Indic. 36:169-177. doi:10.1016/j. ecolind.2013.07.003.

Kokkali A, Vassilopoulou V, Issaris Y, Kavvadas S, Karris G, Fric J, Panayotidis P. 2014. Using Geographic Information Systems (GIS) to map human activities and ecosystem components as the basis for effective Marine Spatial Planning. 12th International Conference on Protection and Restoration of the Environment; Skiathos, Greece. p. 1016-1021.

Larasati LD. 2017. Tantangan internal dalam mewujudkan Indonesia sebagai poros maritim dunia [Internal challenges in realizing Indonesia as the world maritime axis]. Hubungan Internasional. (2):99-116.

Longdill PC. 2008. Environmentally sustainable aquaculture: an eco-physical perspective [dissertation]. [Hamilton]: University of Waikato. https://hdl.handle .net/10289/2604. 
Maina J, Jones K, Hicks C, McClanahan T, Watson J, Tuda A, Andréfouët S. 2015. Designing climate-resilient marine protected area networks by combining remotely sensed coral reef habitat with coastal multi-use maps. Remote Sens. 7(12):16571-16587. doi:10.3390/rs712158 49.

Ministry of Maritime Affairs and Fisheries Indonesia. 2013. Technical Guidelines for Provincial RZWP3K Preparation.

Nainggolan PP. 2016. Kebijakan poros maritim dunia Joko Widodo dan implikasi internasionalnya [Joko Widodo's world maritime axis policy and its international implications]. Jurnal Politica Dinamika Masalah Politik Dalam Negeri dan Hubungan Internasional. 6(2). doi:10.22212 /jp.v6i2.312.

Norse EA. 2010. Ecosystem-based spatial planning and management of marine fisheries: why and how? Bull Mar Sci. 86(2):179-195.

Ouellette W, Getinet W. 2016. Remote sensing for Marine Spatial Planning and Integrated Coastal Areas Management: achievements, challenges, opportunities and future prospects. Remote Sens Appl: Soc Environ. 4:138157. doi:10.1016/j.rsase.2016.07.003.

Paxinos R, Wright A, Day V, Emmett J, Frankiewicz D, Goecker M. 2008. Marine spatial planning: ecosystembased zoning methodology for marine management in South Australia. J Conserv Plann. 4:37-59.

Pereira HM, Ferrier S, Walters M, Geller GN, Jongman RH, Scholes RJ, Bruford MW, Brummitt N, Butchart SH, Cardoso AC, Coops NC, Dulloo E, Faith DP, Freyhof J, Gregory RD, Heip C, Höft R, Hurtt G, Jetz W, Karp DS, McGeoch MA, Obura D, Onoda Y, Pettorelli N, Reyers B, Sayre R, Scharlemann JP, Stuart SN, Turak E, Walpole M, Wegmann M. 2013. Essential biodiversity variables. Science. 339(6117):277-278. doi:10.1126/science.1229931.

Pribadi R. 2018. Isu strategis \& info kebijakan [Strategies issues \& policy info]. Spatial \& Atlas Newsletter.

Requena-Mullor JM, López E, Castro AJ, Alcaraz-Segura D,
Castro H, Reyes A, Cabello J. 2017. Remote-sensing based approach to forecast habitat quality under climate change scenarios. PLOS ONE. 12(3):e0172107. doi: 10.1371/journal.pone.0172107.

Santos AMP. 2000. Fisheries oceanography using satellite and airborne remote sensing methods: a review. Fish Res. 49(1):1-20. doi:10.1016/S0165-7836(00)00201-0.

Sarno. 2013. Model diseminasi informasi geospasial pulaupulau kecil terluar berbasis pemanfaatan penginderaan jauh dan Google mapping system [Geospatial information dissemination model of outlying islands based on remote sensing utilization and Google mapping system]. Penginderaan Jauh. 10(2):59-70.

Shalihati SF. 2014. Remote sensing and geographic information systems utilization in the marine sector and the maritime national defense system developments. Geoedukasi. 3(2):115-126.

Stamoulis KA, Delevaux JM. 2015. Data requirements and tools to operationalize marine spatial planning in the United States. Ocean Coastal Manage. 116:214-223. doi: 10.1016/j.ocecoaman.2015.07.011.

Swardika IK, Tanaka T, Ishida H. 2012. Study on the characteristics of the Indonesian seas using satellite remote-sensing data for 1998-2007. Int J Remote Sens. 33(8):2378-2394. doi:10.1080/01431161.2011.608739.

Syofyan I, Jhonerie R, Siregar YI. 2010. Geographic information systems application in suitability of fishing net and seaweed cages determinations in Bunguran Island Natuna Regency. Perikanan dan Kelautan. 15(2):111-120.

Vold T, Buffett D, editors. 2008. Ecological concepts, principles, and application to conservation. Victoria: Biodiversity BC. http://www.biodiversitybc.org/assets/pr essReleases/BBCPrinciplesWEB.pdf.

Zainuddin M, Kiyofuji H, Saitoh K, Saitoh SI. 2006. Using multi-sensor satellite remote sensing and catch data to detect ocean hot spots for albacore (Thunnus alalunga) in the northwestern North Pacific. Deep Sea Res, Part II. 53(3-4):419-431. doi:10.1016/j.dsr2.2006.01.007. 